\title{
Gender Analysis in Development of Economic and Education Sector in Bekasi Regency
}

\author{
Suharjuddin $^{1}$, Zahara Tussoleha Rony ${ }^{2}$, Nofal Supriaddin ${ }^{3}$, Sani Ariyanto ${ }^{4}$ \\ \{suharjuddin@dsn.ubharajaya.ac.id $\left.{ }^{1}\right\}$ \\ Elementary School Teacher Education, Universitas Bhayangkara Jakarta Raya, Indonesia ${ }^{1,4}$ \\ Management, Universitas Bhayangkara Jakarta Raya, Indonesia ${ }^{2}$ \\ Management, STIE 66 Kendari, Indonesia ${ }^{3}$
}

\begin{abstract}
Nowadays, world's attention towards gender based development which accommodate women rights is getting bigger and more serious. Development has important roles in the progress of a nation. Implementation of development programs in Bekasi regency has tried to put public welfare as the priority. But in fact, in justice and inequality based on gender still occurred. The objective of this research is to provide big data and reveal issues regarding to gender analysis which is collected simultaneously, actual and comprehensive in order to formulation of planning and decision making related to sustainable development in Bekasi Regency. This research was descriptive analysis model by using combination of qualitative and quantitative data collected from particularly in the development in economic and education sector. Conclusion, based on Gender Pathway Analysis founded that the GDI in Bekasi Regency is still low. Therefore, formulation of development in Bekasi need to involves gender analysis and gender mainstreaming concept into action. The implication, through this gender analysis, formulation of development in Bekasi needs to create more responsive gender in the development concept.
\end{abstract}

Keywords: Gender analysis, development, education, economic, GDI

\section{Introduction}

The objective of national development is to create prosperous, welfare and justice life by focusing on human being both to individual and society. The result of development needs to be perceived by all level of society. But in fact, participation of women in development is still low, gender injustice and discrimination are existing as the impact of development which rely on social structure and infrastructures. As the consequence, nationally since 2010 until 2018, there is a deep gap in Human Development Index between men and women and also followed by the fact that gender development gap is higher and deeper. Female participation in socioeconomic development initiatives has been considered crucial not only for fueling economic growth but also for enhancing gender equality in many low and lower-middle income countries [1].

In Bekasi regency, $51,4 \%$ of the total population is women. In number, women is higher. But the big question is how the quality of women is in Bekasi regency? Does the development in Bekasi has put gender mainstream as one of their strategy? Responsive gender strategy in implementing development is very important. Gender role as strategy for responsive gender development has been spread rapidly worldwide. (Akpa and Ekenta, 2020) explained that in gender role, men strongly agreed that males should also be doing domestic work in the family 
and women should be involved in paid jobs, economic, politic, education and soon. This present paper describes and elaborates the gender analysis in two main sector; economic and education. This two sectors have significant effect on HDI and GDI in Bekasi Regency in elaborating economic sector the data focus on workforce, potential poverty, and land ownership. In elaborating education sector, the data focus on numbers of teacher and headmasters. It is also critically the effectiveness of development which has not put responsive gender as one of development strategy. This research is aimed to get comprehensive data by doing gender analysis by comparing HDI and GDI, and comparing GDI on economic and education sector.

\section{Method}

This research was conducted in Bekasi Regency within 8 month's duration of collecting data. This research used qualitative research. The research steps: (1) Field grand, (2) Observation and data collection (3) data analysis. The procedure on answering the objective of the research was conducted by determining research question in general, and then selecting relevant locus and subject of research and continued by collecting relevant data. Direct observation, in-depth interview (structured and unstructured interview), making documentation were conducted simultaneously in finding the data. Random observation was conducted on natural situation in the whole 23 districts and government agencies in Bekasi Regency. The unscheduled and without appointment observation was selected to get natural and real data. The data found was analyzed and interpreted. The next procedure is working on conceptual and theoretical work and making conclusion. To get accurate and reliable data, data was take from various competent resources purposively (Executive government of Bekasi, Head of Departments (OPD), Central Bureau of Statistic). The procedure of data analysis followed model of Miles and Huberman: (1) data reduction, (2) data display, and (3) conclusion drawing/verification. Data found was analyzed by selecting relevant data, specific coding was used to help researcher to display data. Procedure of data validity covered credibility, transferability, dependability and conformability.

\section{Result and Discussion}

\subsection{Analysis gender on economic sector}

In elaborating economic sector, this paper focused on three aspects: workforce, potential poverty, and land ownership. Bekasi regency is the biggest industrial area not only in Indonesia, but also in Southeast Asia. As industrial regency, there are potential job opportunities. To clarify that opportunity, observe the following Table 1.

Equality to get job between men and women is guaranteed in Indonesian constitution, article 28D paragraph (2) states that everyone has right to work and get wage and treat in fair and justice as well as proper in work relationship. In fact, women get lower salary than men. Female worker paid lower than men, is about $77,8 \%$ from salary paid for male worker [3]

The workforce participation rate provides an indication that there is big gap between men and women. The number of working men is 2 times higher than women. Many factors can explain this phenomenon. The gender gap is most obvious in the labor market, where women 
often face greater barriers than men in terms of securing a decent job, wages and conducive working condition [4].

Tabel 1. Number of workforce in Bekasi Regency in 2019

\begin{tabular}{lrrr}
\hline \multicolumn{1}{c}{ Types } & Men & Women & Total \\
\hline Workforce & & & \\
Working & 928,788 & 416,033 & $1,344,821$ \\
Not Working & 92,859 & 57,000 & 149,859 \\
\hline Not Workforce & & & \\
Study/School & 120,976 & 103,305 & 229,281 \\
Home Care & 9,546 & 550,523 & 560,069 \\
Others & 51,879 & 30,038 & 81,917 \\
\hline
\end{tabular}

Tabel 2. Number of potential poverty in Bekasi Regency in 2019

\begin{tabular}{llll}
\hline No & Year & $\begin{array}{l}\text { Number of Risky Women in } \\
\text { Social Economy }\end{array}$ & $\begin{array}{l}\text { Number of Poor People } \\
\text { (Women) }\end{array}$ \\
\hline 1. & 2015 & 2,866 & N/A \\
2. & 2016 & 2,866 & 50,458 \\
3. & 2017 & 4,106 & 108,975 \\
4. & 2018 & 38,945 & 595,230 \\
5. & 2019 & 26,482 & 542,318 \\
\hline
\end{tabular}

Table 2 shows the number of potential poverty which significantly increases from year to year. It indicates that the result of development is not equally perceived and not responsive gender. Critical input needs to be given to the local government in order to put responsive gender strategy in action as soon as possible to reduce the number of poor women. It is an interesting fact that Indonesia is a large country with many populations living in rural areas but so far there is no poverty reduction especially for women [5]. Women participation in development through the economic sector will reduce those numbers. Everyone, no matter from which socialeconomic level they come from has the right to take benefit from the development process. If one of the group is left behind, thus the development may be assumed to have failed [6].

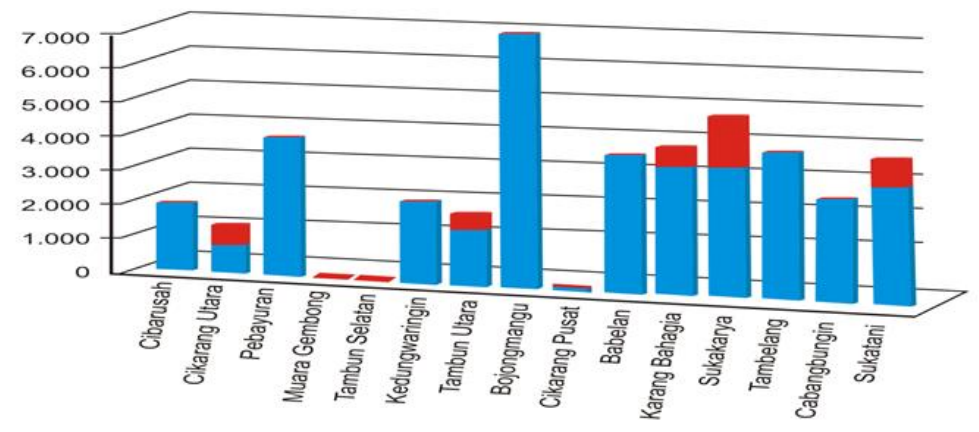


Fig. 1. Ownership of Farming in Bekasi Regency in 2019

The third aspect analyzed is ownership of land farming in 15 districts from 23 districts in Bekasi Regency. Very deep gap exists. Majority land farming is owned by men and only very small number owned by women. Women contribution on economic sector through farming mostly represent as active worker, not as owner. Females involved in household activities as well as agriculture households assist the farmers in fields. They also participate in all agricultural activities like crop production, input allocation, processing and storage [7].

\subsection{Analysis gender on education sector}

In elaborating education sector, this paper focused on two aspects: number of teachers and headmasters. These two aspects were selected due to still few discussions on those topics regarding to research about gender analysis on education sector.

Tabel 3. Number of teachers in Bekasi Regency in 2019

\begin{tabular}{llll}
\hline School Level & Men & Women & Total \\
\hline Elementary & 4,527 & 8,963 & 13,490 \\
Junior High & 2,283 & 2,886 & 5,169 \\
Senior High & 1,036 & 1,317 & 2,353 \\
Vacational & 1,379 & 1,209 & 2,588 \\
Number & 9,225 & 14,375 & 23,600 \\
\hline
\end{tabular}

Based on the Table 3 above, total number of female teachers is bigger that male teachers. It happened in almost all school level except in vocational school in which number of male teacher is slightly higher than female teachers. In fact more female teacher are exist due to shifting paradigm on women. Women is not only focus on doing household activities, but they also take apart in many aspect of life as men do. In terms of formal education, year by year, more women put much concern on their study and more women go to university [8].

Tabel 4. Number of Headmasters in Bekasi Regency in 2019

\begin{tabular}{cccc}
\hline Year & Men & Women & Total \\
\hline 2019 & 1,187 & 731 & 1,918 \\
\hline
\end{tabular}

By concerning that number of teachers is dominated significantly by female teachers, very sad to see the reality in numbers of headmasters. Male headmasters dominated top leader in school. Men and women have the same right to get position as headmaster. Educational bureaucrat must increase their awareness and sensitivity and not always use bias standard in deciding policy to transform into gender perspective education [8]. Participation of women in process of management, decision making and many other aspect in education is still low. This gap need intervention from government to realize equality in gender. There are many hopes rely on women to take part more actively in society. But, in reality the traditional assumption which put women in discrimination such as women is weak, emotional, moody, can't work under pressure, and many others labeling is still exist [9]. 


\section{Conclusion}

This research conclude that the effect of development, particularly in economic and educational sector was not perceived equally between men and women. Based on gender analysis on the two aspects, men get more benefit from the development which is still not put responsive gender strategy as priority. From the aspect of economic and education sector, there is deep and high gap in gender development index between men and women. Eventough in number, population of women is higher than men, but the gender development index in economic and education put men is higher than women. Sensitive and responsive gender strategy in development needs to take into action in the coming years.

\section{Acknowledgements}

I would like to dedicate my greatest appreciation to all parties who has given positive contribution on this research. Particularly to regional government of Bekasi regency. That's a lot for the very good collaboration and cooperation. Secondly, my deepest thank to all colleague in education faculty of Bhayangkara Jakarta Raya University and LPPMP of Bhayangkara Jakarta Raya University Unit which funded this research.

\section{References}

[1] R. Karim, L. Lindberg, S. Wamala, and M. Emmelin, "Men's Perceptions of Women's Participation in Development Initiatives in Rural Bangladesh," Am. J. Mens. Health, vol. 12, no. 2, pp. 398-410, 2018, doi: $10.1177 / 1557988317735394$.

[2] I. Journal, S. June, T. Author, A. R. Reserved, and P. D. Doi, "Public Perceptions of Changing Gender Roles and Relations in the Family: A Study of Kaduna Metropolis, Kaduna State, Nigeria represents men 's space : it implies freedom for work and even for reprehensible behaviours such as drinking and infidelity .," vol. 8, no. 1, pp. 27-32, 2020, doi: 10.15640/ijgws.v8n1p3.

[3] S. Susiana, "Perlindungan Hak Pekerja Perempuan dalam Perspektif Feminisme," Aspir. J. Masal. Sos., vol. 8, no. 2, pp. 207-222, 2017.

[4] S. Tewari, R. Chouhan, and Sanjeev, "Gender Gap Index for Employment Opportunity," Int. J. Eng. Technol. Manag. Res., vol. 4, no. 9, pp. 39-48, 2020, doi: 10.29121/ijetmr.v4.i9.2017.98.

[5] S. Adeni, "Information Communication Technology (ICT) and Women Empowerment for Rural Area," J. InterAct, vol. 5, no. 2, pp. 1-15, 2016, [Online]. Available: http://ojs.atmajaya.ac.id/index.php/fiabikom/article/view/755.

[6] D. R. Banjarani and R. Andreas, "Perlindungan dan Akses Hak Pekerja Wanita di Indonesia: Telaah Undang-Undang Nomor 13 Tahun 2003 tentang Ketenagakerjaan Atas Konvensi ILO,” J. HAM, vol. 10, no. 1, p. 115, 2019, doi: 10.30641/ham.2019.10.115-126.

[7] N. Awan and N. Khan, "Critical Review On Past Literature Of Women Decision Participation In Income Generating Activities In The World," no. February, 2018.

[8] M. A. Najih, "Gender Dan Kemajuan Terknologi," vol. 12, no. 2, pp. 18-26, 2017.

[9] I. Ahdiah, "Peran-Peran Perempuan dalam Masyarakat," J. Acad., vol. 05, no. 02, pp. 1085-1092, 2013. 